\title{
СЛАВНИЙ ЮВІЛЕЙ ОСТЯКА РОМАНА-ЙОСИФА СТЕПАНОВИЧА
}

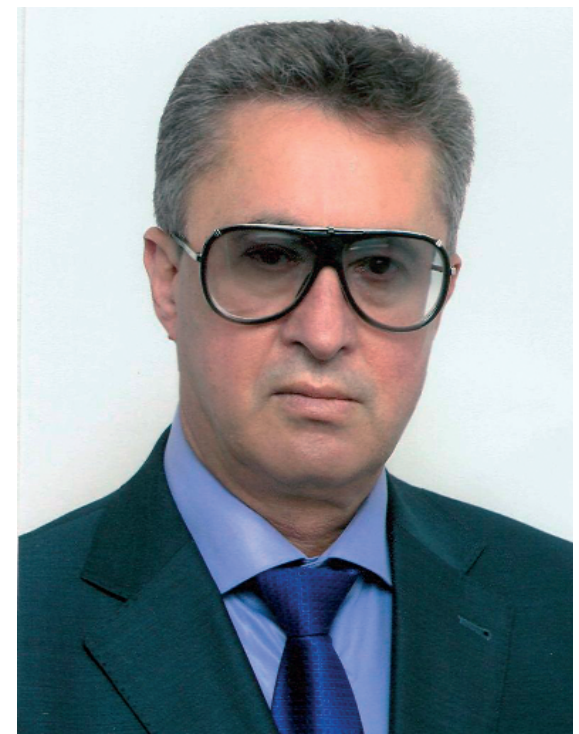

Висвітлено основні біографрічні віхи та творчі досягнення головного лікаря Івано-Франківської обласної клінічної інфрекційної лікарні, Заслуженого лікаря України, члена президії ГО «Всеукраїнська асоціація інфрекціоністів» Остяка Романа-Йосифра Степановича.

Роман-Йосифр Степанович Остяк народився 15 вересня 1950 року у с. Кукільники Галицького району Івано-Франківської області. Після закінчення Івано-Франківського державного медичного інституту у 1973 році був направлений на роботу в м. Коростень Житомирської області, працював лікарем-інфекціоністом Коростенського міськоб'єднання.

У 1980-1982 роках навчався в клінічній ординатурі за спеціальністю «Анестезіологія та реаніматологія», а у 19831985-их завершив заочну аспірантуру за спеціальністю «Інфекційні хвороби» при Івано-Франківському державному медичному інституті. 31982 року працює в клінічній інсекційній лікарні. В березні 1992 року призначений на посаду головного лікаря. У 1995-1997 роках очолював медичне управління міськвиконкому. У вересні 1997 року повернувся працювати головним лікарем Івано-Франківської обласної клінічної інфекційної лікарні.

Роман-Йосиф Остяк - головний позаштатний інфеекціоніст Департаменту охорони здоров'я обласної державної адміністрації. Він має вищу кваліфрікаційну категорію за спеціальностями «Інфекційні хвороби», «Організація та управління охороною здоров'я». Він також $є$ секретарем Обласної координаційної ради з питань протидії туберкульозу та ВІЛ-інфекції/СНІДу. В 2008 році Р.С. Остяку присвоєно почесне звання заслуженого лікаря України. Користується заслуженим авторитетом серед жителів області.

$€$ автором і співавтором 98 наукових робіт, низки рацпропозицій, 2 винаходів, 3 патентів на корисну модель та 2 методичних рекомендацій з лікування та діагностики інфрекційних хвороб. Брав участь у розробці стандартів надання допомоги інсекційним хворим в амбулаторно-поліклінічних умовах Міністерства охорони здоров'я України.

У 2003 році пройшов стажування з організації надання соціально-медичної допомоги ВІЛ-інорікованим та хворим 3 наркоманіями при Ketteric University (штат Мічиган, США). У 2004 році в м. Кракові (Польща) освоїв систему «МОНАР». Був учасником Міжнародних конференцій лікарів-інфекціоністів у Санкт-Петербурзі та Москві, з"їздів інфекціоністів Росії та України, Європейського й Світового конгресів лікарів-українців та з"їздів Всеукраїнського лікарського товариства. Пройшов медичну практику за 4 медичними спеціальностями. Брав участь у проекті Програми розвитку ООН «Врядування з питань ВІЛ/СНІДу», у діяльності проєкту Німецько-технічного співробітництва (GIZ), у впровадженні системи моніторингу та оцінки (МIO) заходів з протидії епідемії ВІЛ-інфекції/СНІДу в Івано-Франківській області, а також в період 2017-2018рр. як головний лікар ІваноФранківської обласної клінічної інфекційної лікарні пройшов стажування з профрілактики та лікування ко-інфекції/ВІЛ і хронічних вірусних гепатитів в Любляні (Словенія) та Севільї (Іспанія).

У 2007 році лікарня нагороджена дипломом рейтингового видання «Ділова Івано-Франківщина» та занесена в літопис «Почесні імена України» (Еліта держави - 2011) та до видання «Флагмани сучасної медицини» в 2014 році.

В 2003 році на базі лікарні організовано обласний центр профрілактики ВІЛ-інфекції та СНІДу, під який реконструйовано корпус площею 742 кв. м., що дало можливість відкрити 14 кабінетів, в яких розміщено амбулаторно-поліклінічне відділення, відділення епідеміологічного моніторингу та лабораторне відділення центру СНІДу, в якому відкрито лабораторію скринінгових та підтверджувальних дослі- 


\section{ЮВІЛЕї ТА ПОДії}

джень на ВІЛ/СНІД і лабораторію для визначення вірусного навантаження.

У 2006 та 2009 роках введено в експлуатацію два нові корпуси лікарні.

28 серпня 2014 року на території лікарні відкрито перший в Україні пам'ятник медичним працівникам «Пам'ятаємо BCix»

У 2015 році Обласна клінічна інфекційна лікарня пройшла чергову акредитацію з підтвердженням вищої категорії. Тут інтенсивно впроваджуються новітні медичні технології, найсучасніші методи діагностики та лікування. Помітного розвитку зазнали діагностичні служби.

Подальшого розвитку набула і лабораторна діагностика. На придбаній новій апаратурі запроваджено 79 методик, необхідних для діагностики та контролю лікування хворих на ВІЛ/СНІД, проводяться бактеріологічні та цитохімічні дослідження.

Вперше в Івано-Франківській області створено гепатологічний центр. У лікарні успішно реалізується Програма лікування вірусних гепатитів.

32014 року в закладі запроваджена система управління якістю. У липні 2015 року Івано-Франківська обласна клінічна інфекційна лікарня виграла грант Міжнародного Альянсу ВІЛ/СНІД з лікування хворих з хронічним гепатитом С препаратом сосросбувір.

З 2014 року головний лікар Івано-Франківської обласної клінічної інсрекційної лікарні Р.С. Остяк є членом президії Всеукраїнської асоціації інорекціоністів. Його слушні пропозиції і поради впроваджуються на державному рівні.
Численні співробітники, колеги і друзі сердечно вітають Романа Степановича Остяка зі славним 70-річчям і бажають міцного здоров'я, невичерпної енергії, нових творчих досягнень та оптимізму.

Кафредра інфрекційних хвороб з курсом епідеміології і кафредра дитячих інфрекцій Івано-Франківського національного медичного університету,

президія ГО «Всеукраїнська асоціація інсрекціоністів», колектив Івано-Франківської обласної клінічної інфрекційної лікарні з обласним Центром боротьби і профрілактики ВІЛ-інфекції, СНІДу, колеги, друзі.

\section{OSTIAK ROMAN-YOSYF'S STEPANOVYCH GLORIOUS ANNIVERSARY}

SUMMARY. The main biographical milestones and creative achievements of the chief physician of IvanoFrankivsk Regional Clinical Infectious Diseases Hospital, Honored Physician of Ukraine, member of the presidium of the Association of Infectious Diseases of Ukraine Ostiak Roman-Yosyf Stepanovych are highlighted.

Конфрлікту інтересів немає.

The authors have no conflicts of interest to declare. Отримано 20.09.2020 p. 